\title{
Asparagus sekukuniensis (Oberm.) Fellingham \& N.L.Mey.: A threatened medicinal plant species used by Vhavenda in the Soutpansberg Region, Vhembe Biosphere Reserve, Limpopo province, South Africa
}

\author{
Luambo Jeffrey Ramarumo ${ }^{1 *}$, Alfred Maroyi ${ }^{1}$, Milingoni Peter Tshisikhawe ${ }^{2}$ \\ ${ }^{1}$ Department of Botany, Faculty of Science and Agriculture, University of Fort Hare, Alice, South Africa. \\ ${ }^{2}$ Department of Botany, School of Mathematical and Natural Sciences, University of Venda, Thohoyandou, South Africa.
}

\author{
ARTICLE INFO \\ Received on: 17/02/2019 \\ Accepted on: 22/03/2019 \\ Available online: 05/06/2019 \\ Key words: \\ Asparagus sekukuniensis, \\ ethnomedicinal uses, \\ Soutpansberg Region, \\ threatened plant species, \\ Vhavenda people, Vhembe \\ Biosphere Reserve.
}

\begin{abstract}
Asparagus sekukuniensis is at risk of extinction in South Africa due to over-collection as herbal medicine. However, there is a scant of literature on the diseases cured by the species, parts used, dosage, and how it is administered. Therefore, this study was aimed at documenting ethnomedicinal uses of A. sekukuniensis, in the Soutpansberg Region, Vhembe Biosphere Reserve, Limpopo province, South Africa. Data on ethnomedicinal uses of A. sekukuniensis were gathered with an aid of semi-structured dialogues, observations, and guided field walk by 125 participants between May and December 2018. Among the participants, laypeople were $35.2 \%$ and subsistence farmers were $14.4 \%$. Specialist herbal healers include child health-care healers $(29.6 \%)$, wound healers $(11.2 \%)$, and general healers (9.6\%). The recorded uses of $A$. sekukuniensis include the enhancement of fontanelle closure in an infant (24.8\%), convulsions in an infant (22.4\%), vaccinating epilepsy in an infant (17.6\%), unhealed or cancer-related wounds (15.2\%), genital wounds $(12.0 \%)$, and boils $(8.0 \%)$. Asparagus sekukuniensis appeared to be an important herbal medicine against infant ailments, wounds, infections, and infestations. These findings, therefore, call for an evaluation of the phytochemical and pharmacological properties of this species.
\end{abstract}

\section{INTRODUCTION}

Local people throughout the world have been using medicinal plants to maintain their well-being since time immemorial (Fabricant and Farnsworth, 2001; Falah and Hadiwibowo, 2017; Lulekal et al., 2013; Manzo et al., 2017; Saive et al., 2018; Yazdanshenas et al., 2016). Traditional medicines have also been the fundamental source of modern medicine, drug discovery, and synthesis (Qasim et al., 2014; Stanley et al., 2014). Traditional medicines are considered to be highly effective in the treatment of assorted illnesses (Rokaya et al., 2014). Up

\section{"Corresponding Author}

Luambo Jeffrey Ramarumo, Department of Botany, Faculty of Science and Agriculture, University of Fort Hare, Alice, South Africa.

E-mail:luambo@safrica.comor201816821@ufh.ac.za to date, more than $70 \%$ of people in the third world countries use traditional medicines as an alternative to primary health care (Chen et al., 2016; Kayani et al., 2014; Mahomoodally, 2013; Maroyi, 2011; Mazid et al., 2012; Scott et al., 2004; Sigidi et al., 2016). According to Mander et al. (2007), about 27 million native South Africans still rely upon traditional medicines for treating a range of health problems. Among the utilized species, there are taxa that are threatened with extinction due to overharvesting and habitat destruction (Harisha and Padmavathy, 2013; Kala and Sajwan, 2007). The habit of using threatened medicinal plant species by both village and city communities countrywide and across the globe continues despite the available legal implications set to restrict their collection (Kala, 2005; Ndhlala et al., 2011; Zschocke et al., 2000). Regardless of the availability and accessibility of modern medicines countrywide and worldwide (Seshathri, 2012), a large number of dwellers in the Soutpansberg Region continues to rely on and habitually 
preferred the use of herbal medicines without considering their conservation status. The high demand of plant resources due to their medicinal properties has been a major cause of threatened species decline (Van Andel et al., 2015; Williams et al., 2013; Yao et al., 2012), including the species belonging to genus Asparagus L. (Asparagaceae).

It is evident that many species within the genus, Asparagus are being used for medicinal or ornamentals (Goyal et al., 2003; Norup et al., 2015), and they are also listed as either Endangered, Vulnerable, or Near Threatened (Raimondo et al., 2009). The genus Asparagus L. is considered to have more than 200 species distributed within the arid and semi-arid zones worldwide (Fukuda et al., 2005; Kubota et al., 2012). About 120 species, including Asparagus sekukuniensis have been recorded in Southern Africa, Europe, and Asia (Batchelor and Scott, 2006; Fellingham and Meyer, 1995). Asparagus sekukuniensis is endemic to the Limpopo province, South Africa and categorized as Endangered as its habitat is widely transformed and degraded due to mining, new settlement development, over-grazing, crop cultivation, and over-collection as an herbal medicine (Burrows et al., 2012; Mukhopadhyay and Ray, 2013). However, there is a scant of literature on the diseases cured by the species, parts used, dosage, and how this species is administered in the traditional health care systems. Therefore, this study aimed at documenting ethnomedicinal uses of $A$. sekukuniensis, in the Soutpansberg Region, Vhembe Biosphere Reserve, Limpopo province, South Africa. As like in other aboriginal cultural communities worldwide (Bhat et al., 2013), a large amount of knowledge about the medicinal use of A. sekukuniensis in Soutpansberg's traditional health care systems is transmitted orally and this wealth of knowledge need to be documented to avoid its subsequent loss. This could not only preserve the Vhavenda's traditional health care systems and knowledge but also provide baseline data needed for advanced research on the species.

\section{MATERIALS AND METHODS}

\section{Study site description}

The current investigation was conducted in four subvillages of a Vhulaudzi village in Soutpansberg East, Vhembe Biosphere Reserve, Limpopo province, South Africa (Fig. 1 and Table 1). Study sites were located within the north-eastern region of the Makhado Local Municipality, along the Witflag road to Tshikombani which diverge from N1 north route at approximately $3.5 \mathrm{~km}$ from Louis Trichard Makhodo (Fig. 1 and Table 1). The study sites covered the combined surface area of roughly $6.99 \mathrm{~km}^{2}$, with the combined estimated population size of 8276 people (Census, 2011). The study sites are predominantly occupied by the black ethnic group of Vhavenda tribe, who also speak Tshivenda as their native language. Vegetation type of study sites is considered to be savanna bushveld (Luseba and Tshisikhawe, 2013). Climatically, the study sites are described by a warm-wet summer (span from October to April) and cold-dry winter (May to September) (Edokpayi et al., 2016; Gumbo et al., 2016; Kephe et al., 2016), with an average annual rainfall range from $300 \mathrm{~mm}$ (winter season) to $820 \mathrm{~mm}$ (Summer season) (Mpandeli, 2014), and the average annual temperature range from $20^{\circ} \mathrm{C}$ during the winter season and $30^{\circ} \mathrm{C}$ in summer (Mzezewa and Rensburg, 2011). The topography and geological features of the study sites include Bushveld Igneas complexity, Karoo systems, Limpopo Belt Archaean Cratons, Kalahari Cratons, and the Wylies Poort geological formation of the Soutpansberg Group (Barton et al., 2006; Mostert et al., 2008).

\section{Ethnobotanical data collection and analysis}

Ethnobotanical data about the medicinal uses and administration of $A$. sekukuniensis in the treatment of various ailments were gathered from May to December 2018, with an aid of semi-structured dialogues with participants. A total number of 125 participants were arbitrarily chosen, and prior signed informed consent permitted by the University of Fort Hare Research Ethic Committee (Reference no. MAR031SRAM01) was obtained from all of them. Among the participants, 44 were laypeople $(35.2 \%), 18$ were subsistence farmers $(14.4 \%)$, and the combined total of 63 specialists were herbal-healers $(50.4 \%)$ (Fig. 2). Among specialist herbal healers, there was 37 child health-care healer $(29.6 \%), 14$ wound healers $(11.2 \%)$, and 12 general healers (9.6\%) (Fig. 2). To intensify the participation confident and smooth flow of ideas amongst the interviewees, face-to-face dialogues were carried-out together with all the participants, at the individual level, using their own local language (Tshivenda). To maintain the high-level standard of legitimacy, accuracy and validity of the given answers during the interview sessions, equivalent questions were administered to all the participants of this study. Gathered data were kept in a Microsoft Office spreadsheet program and later analyzed using

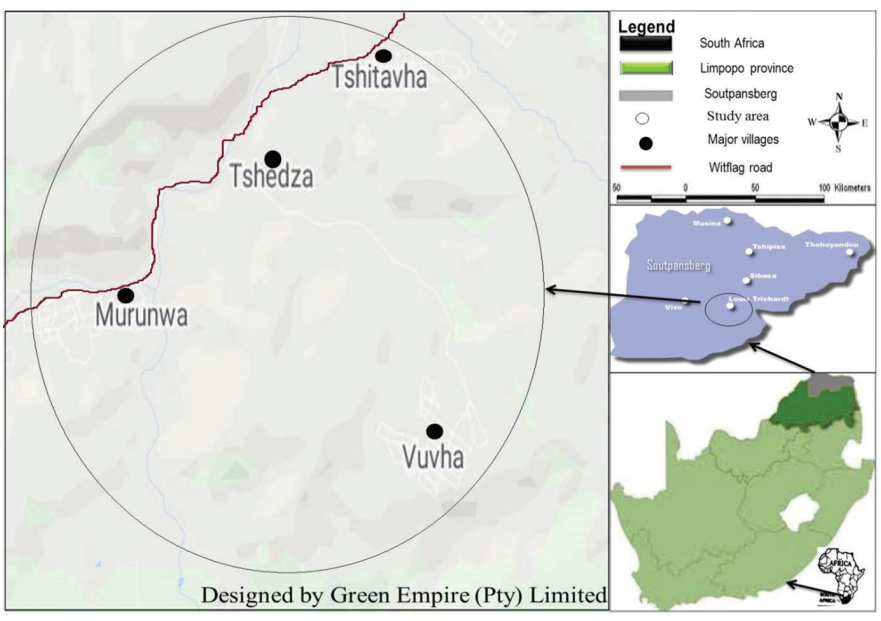

Figure 1. Locality map of the study areas

Table 1. Coordinates of the location of the study areas.

\begin{tabular}{lcc}
\hline $\begin{array}{l}\text { Vhulaudzi } \\
\text { sub-villages }\end{array}$ & Latitudes & Longitudes \\
\hline Muruniwa village & $-22^{\circ} 58^{\prime} 23.31^{\prime \prime} \mathrm{S} ;-22^{\circ} 58^{\prime} 55.94^{\prime \prime} \mathrm{S}$ & $30^{\circ} 9^{\prime} 19.89^{\prime \prime} \mathrm{E} ; 30^{\circ} 10^{\prime} 1.37^{\prime \prime} \mathrm{E}$ \\
Tshedza village & $-22^{\circ} 58^{\prime} 6.77^{\prime \prime} \mathrm{S} ;-22^{\circ} 58^{\prime} 28.53^{\prime \prime} \mathrm{S}$ & $30^{\circ} 10^{\prime} 31.56^{\prime \prime} \mathrm{E} ; 30^{\circ} 11^{\prime} 41.36^{\prime \prime} \mathrm{E}$ \\
Tshitavha village & $-22^{\circ} 57^{\prime} 51.76^{\prime \prime} \mathrm{S} ;-22^{\circ} 57^{\prime} 41.67^{\prime \prime} \mathrm{S}$ & $30^{\circ} 10^{\prime} 47.55^{\prime \prime} \mathrm{E} ; 30^{\circ} 12^{\prime} 26.35^{\prime \prime} \mathrm{E}$ \\
Vuvha village & $-22^{\circ} 59^{\prime} 13.26^{\prime \prime} \mathrm{S} ;-22^{\circ} 59^{\prime} 39.93^{\prime \prime} \mathrm{S}$ & $30^{\circ} 11^{\prime} 44.13^{\prime \prime} \mathrm{E} ; 30^{\circ} 12^{\prime} 34.04^{\prime \prime} \mathrm{E}$ \\
\hline
\end{tabular}




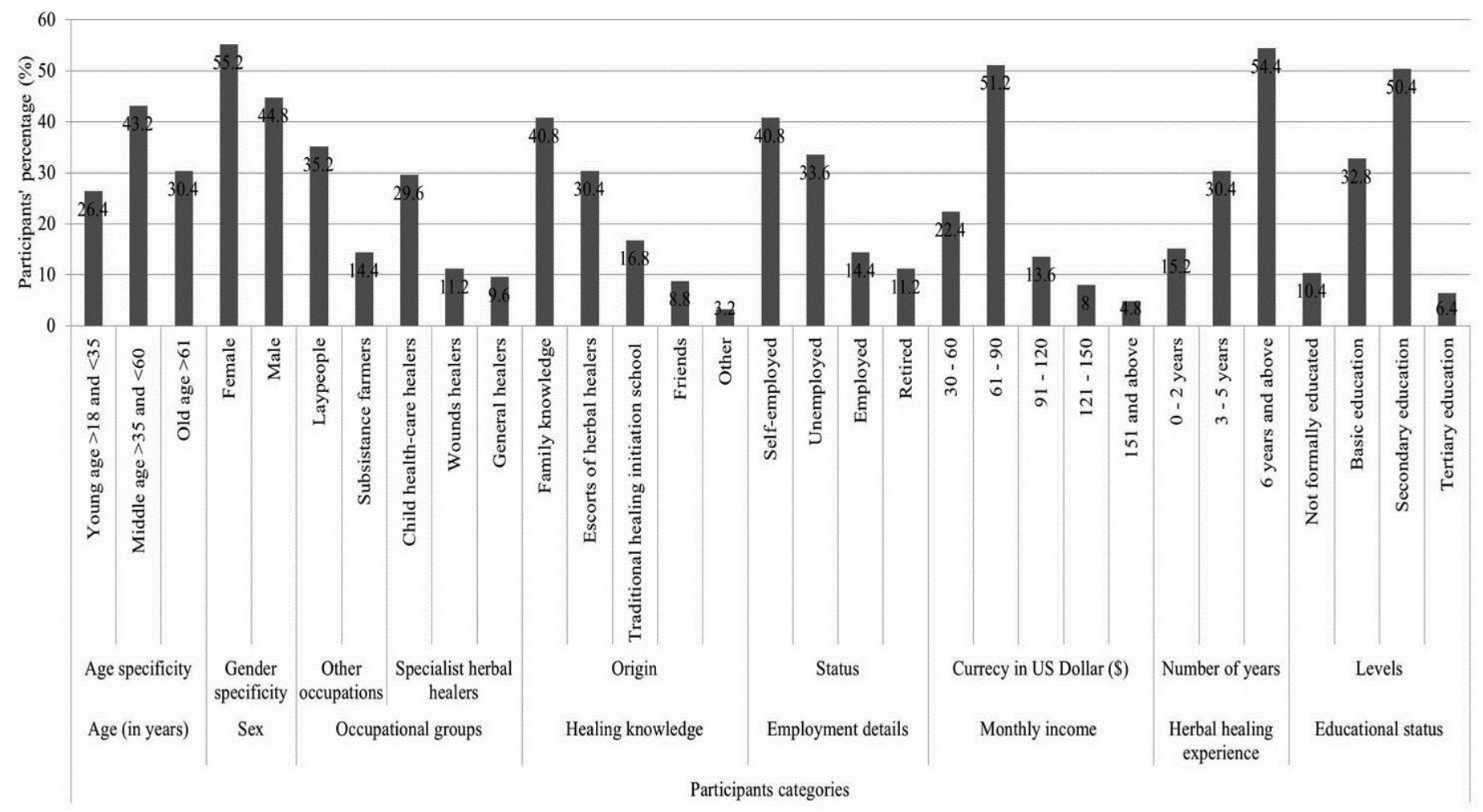

Figure 2. participant's biographical information.

Table 2. Ethnobotanical uses, preparations, and administration [Key: A—Mabogo (1990), F—-frequency, and FL (\%)—fidelity level percentage] (Note: Asparagus Sekukuniensis is locally known as Lufhaladza makole-lwa-thavha/ Muri-wa-muthuso)

\begin{tabular}{|c|c|c|c|c|c|c|}
\hline Ailments & Used parts & Preparation modes & Administration modes & $F(n=125)$ & FL (\%) & $\begin{array}{l}\text { No. of same } \\
\text { use citations }\end{array}$ \\
\hline $\begin{array}{l}\text { Enhancement of } \\
\text { fontanelle closure } \\
\text { in infants }\end{array}$ & Root & $\begin{array}{l}\text { Burned black ashes are ground into } \\
\text { fine powder and then mixed with } \\
\text { saturated oil }\end{array}$ & $\begin{array}{l}\text { Small cuts are made on the skin around the fontanelle part } \\
\text { using a razor-blade and then medication is administered to } \\
\text { the bleeding area }\end{array}$ & 31 & 24.8 & None \\
\hline $\begin{array}{l}\text { Convulsions in } \\
\text { infants }\end{array}$ & Whole plant & $\begin{array}{l}\text { The grounded powder is mixed with } \\
\text { a fine powder made from barks } \\
\text { of Maerua angolensis DC. subsp. } \\
\text { angolensis. }\end{array}$ & $\begin{array}{l}\text { Small cuts are made around or on different body parts of } \\
\text { the newly born baby using a razor blade to allow blood } \\
\text { to come out and then the medication is administered into } \\
\text { the bleeding area to allow it to enter into the blood stream. } \\
\text { Afterwards, the same mixture of powder is then poured into } \\
\text { a heated clay pot without water while covering the patient } \\
\text { with a blanket to contain the produced smoke }\end{array}$ & 28 & 22.4 & $1(\mathrm{~A})$ \\
\hline $\begin{array}{l}\text { Vaccination of } \\
\text { epilepsy in infants }\end{array}$ & Whole plant & Burnt to produce smoke and ashes. & $\begin{array}{l}\text { The naked newly born baby carried by the herbal } \\
\text { practitioner is moved around the produced smoke three } \\
\text { times per day (morning, afternoon and evening) for the } \\
\text { period of a week. The burned ashes are then mixed with } \\
\text { the urine of the rock rabbit ("Thulo") and then taken orally } \\
\text { twice per day until the newly born baby is two years old. } \\
\text { The mixture of ashes and urine of rock rabbit is called } \\
\text { "Muuluso" }\end{array}$ & 22 & 17.6 & None \\
\hline $\begin{array}{l}\text { Unhealed or } \\
\text { cancer-related } \\
\text { wounds }\end{array}$ & Root & $\begin{array}{l}\text { A decoction of fresh root, dried root is } \\
\text { ground into a fine powder and mixed } \\
\text { with a powder made from the barks of } \\
\text { Ozoroa reticulata (Baker f.) R.Fern. } \\
\text { \& A. Fern }\end{array}$ & $\begin{array}{l}\text { A decoction of fresh roots taken orally whereas, a mixture } \\
\text { of powders is administered into the unhealed wounded } \\
\text { body part }\end{array}$ & 19 & 15.2 & None \\
\hline Genital wounds & Root. & $\begin{array}{l}\text { The dried root is ground into a fine } \\
\text { powder and then mixed with saturated } \\
\text { oil }\end{array}$ & Administered to the wounding area & 15 & 12.0 & None \\
\hline $\begin{array}{l}\text { Boil in both } \\
\text { humans and live } \\
\text { stocks }\end{array}$ & Whole plant & $\begin{array}{l}\text { Fresh materials are boiled to produce } \\
\text { steam }\end{array}$ & $\begin{array}{l}\text { Steam is applied around the area where boil occurs to soften } \\
\text { it so that it gets healed }\end{array}$ & 10 & 8.0 & None \\
\hline
\end{tabular}


components of the descriptive statistic, such as frequency of occurrence and fidelity level (FL) (\%). FLs (\%) were determined using the following formula: FL $(\%)=N_{\mathrm{p}} / N \times 100$, where $\mathrm{FL}$ $(\%)$ is the FL percentage; $N_{\mathrm{p}}$, the number of individuals who cited a certain use, and $N$ is a total number of individuals who cited all the uses (Al-Qura'n, 2009; Umair et al., 2017). Since all participants have cited ethnomedicinal uses of $A$. Sekukuniensis, $N$ was equal to 125 .

\section{Plant identification and specimen collection}

Gathered data were supplemented by field inspection walks together with participants for plant identification purposes and specimen collection. The voucher specimen collection permit (ZA/LP/92932) was granted by the Limpopo Department of Economic Development, Environment and Tourism. During the field inspection walk, participants have identified the plant species of interest using its vernacular name and sample specimen was then collected, prepared (pressed and dried), and numbered (RAMLJ 013). A voucher specimen was then deposited at the Botany Herbarium, Life Science and Chemistry Building, the University of Venda for further identification by taxonomists.

\section{RESULTS AND DISCUSSION}

\section{Ethnomedicinal uses}

Table 2 reports on the recorded ethnomedicinal uses, preparation techniques, and administration procedures of $A$. sekukuniensis by the Vhavenda people in the Soutpansberg Region, Vhembe Biosphere Reserve, Limpopo province, South Africa. A total of six ethnomedicinal uses of A. sekukuniensis were recorded in this study. FL of the six recorded uses ranged from $8.0 \%$ to $24.8 \%$ (Table 2). More than $64.8 \%$ of all the participants in the current study seemed to be communally utilizing A. sekukuniensis for child health care-related ailments (Table 2). According to the participants, ensuring child's health was always an important cultural norm for Vhavenda people in the region and therefore, all newly born infants undergo traditional vaccination rituals to strengthen their immune systems called muthuso (personal communication with the participants). According to Rikhotso (2016), muthuso referred to the use of varied herbal medicines to protect the infants against miscellaneous ailments. The communal use of certain medicinal plant species by various herbal healers proves the effectiveness and therapeutic reliability of these implicated species (Semenya and Maroyi, 2018). Participants across the study sites have stated that they utilized $A$. sekukuniensis for curing the variety of ailments, including enhancement of fontanelle closure in infants $(\mathrm{FL}=24.8 \%)$, convulsions in infants $(\mathrm{FL}=22.4 \%)$, vaccinating epilepsy in infants $(\mathrm{FL}=17.6 \%)$, treating the unhealed or cancerrelated wounds $(\mathrm{FL}=15.2 \%)$, genital wounds $(\mathrm{FL}=12.0 \%)$, as well as boils treatment in both human beings and livestock (FL $=8.0 \%)($ Table 1$)$. Thus, this study argued that the repetitive use of A. sekukuniensis in addressing miscellaneous ailments (Table 2) demonstrates the variety of biological activities it may possess. The aforementioned statement was supported by other scholars worldwide (Cheikhyoussef et al., 2011; Khan et al., 2014; Mojahedi et al., 2014). However, Jamila and Mostafa (2014) argued that the reliability of traditional herbal medicines, in the treatment and prevention of certain ailment, should not be doubted, but phytochemical validated for authenticity.

The utilized parts of $A$. sekukuniensis included roots (50\%) and whole plant (50\%) (Table 2). The equal utilization proportions of $A$. sekukuniensis parts were influenced by the fact that healers do not want to lose any materials of this species since this plant is scanty to be found (personal communication). This was endorsed by the study done by Burrows et al. (2016), whereby A. sekukuniensis was categorized as an Endangered species under the International Union for Conservation of Nature. Furthermore, this study argued that the equal utilization of $A$. sekukuniensis parts demonstrates the equal therapeutic efficacy (Ramarumo et al., 2019). Moreover, the results of this study do not conform to other ethnomedicinal studies in the region since leave was portrayed as the most frequently used plant part (Luseba and Tshisikhawe, 2013; Mahwasane et al., 2013; Masevhe et al., 2015; Mulaudzi et al., 2012).

\section{CONCLUSION}

The current study has enlightened five uses associated with A. sekukuniensis which were never reported elsewhere in the world (Table 2). Asparagus sekukuniensis appeared to be an important herbal medicine against infant ailments, wounds, infections, and infestations. These findings, therefore, call for the evaluation of the phytochemical and pharmacological properties of this species.

\section{ACKNOWLEDGMENTS}

The current study was sponsored by the National Research Foundation (NRF) of South Africa, the University of Fort Hare (NRF Grant No. 112976). The authors would like to direct their gratitudes to Ms Beyi Florence Sekgobela (The traditional healer) together with other participants for their outstanding knowledge sharing and specimen collection.

\section{CONFLICT OF INTERESTS}

The authors declare that they have no conflicts of interest.

\section{ETHICAL APPROVAL}

The ethical authorization of this study was permitted by the University of Fort Hare's Research Ethic Committee (Reference no. MAR031SRAM01).

\section{FINANCIAL SUPPORT}

This study was sponsored by the National Research Foundation (NRF) of South Africa and the University of Fort Hare (NRF Grand number: 112976).

\section{REFERENCES}

Al-Qura'n S. Ethnopharmacological survey of wild medicinal plants in Showbak, Jordan. J Ethnopharmacol, 2009; 123(1):45-50.

Barton JM, Klemd R, Zeh A. The Limpopo belt: a result of Archean to Proterozoic, Turkic-type orogenesis? Spec Paper-Geol Soc Am, 2006; 405:315-332.

Batchelor KL, Scott JK. Review of the current taxonomic status and authorship for Asparagus weeds in Australia. Plant Prot Q, 2006; 21(3):128-130. 
Bhat JA, Kumar M, Bussmann RW. Ecological status and traditional knowledge of medicinal plants in Kedarnath Wildlife Sanctuary of Garhwal Himalaya, India. J Ethnobiol Ethnomed, 2013; 9(1):1.

Burrows JE, Lotter MC, Raimondo D, von Staden L. Asparagus sekukuniensis: the IUCN Red List of Threatened Species 2016: e.T103636792A104106905, 2016 [Online]. Available via http:// dx.doi.org/10.2305/IUCN.UK.2016-3.RLTS.T103636792A104106905.en (Accessed 14 January 2019).

Burrows SM, Burrows JE, Lötter M, Raimondo D, von Staden L. Asparagus sekukuniensis (Oberm.) Fellingham \& N.L.Mey. National Assessment: Red List of South African Plants version 2017.1, 2012 [Online]. Available via http://redlist.sanbi.org/species.php?species=728-94 (Accessed 19 January 2019).

Census. 2011. Makhado local municipality. [Online]. Available via https://census2011.adrianfrith.com/place/968 (Accessed 28 November 2018).

Cheikhyoussef A, Shapi M, Matengu K, Ashekele HM. Ethnobotanical study of indigenous knowledge on medicinal plant use by traditional healers in Oshikoto region, Namibia. J Ethnobiol Ethnomed, 2011; 7(1):10.

Chen SL, Yu H, Luo HM, Wu Q, Li CF, Steinmetz A Conservation and sustainable use of medicinal plants: problems, progress, and prospects. Chinese Med, 2016; 11(1):37.

Edokpayi JN, Odiyo JO, Popoola OE, Msagati TA. Assessment of trace metals contamination of surface water and sediment: a case study of Mvudi River, South Africa. Sustain, 2016; 8(2):135.

Fabricant DS, Farnsworth NR. The value of plants used in traditional medicine for drug discovery. Environ Health Perspect, 2001; 109:69-75.

Falah F, Hadiwibowo N. Species identification of traditional medicine plants for women's health in East Kalimantan: lesson learned from local wisdom. Indonesian J Forest Res, 2017; 4(1):49-67.

Fellingham AC, Meyer NL. New combinations and a complete list of Asparagus species in southern Africa (Asparagaceae). Bothal, 1995; 25(2):205-209.

Fukuda T, Ashizawa H, Suzuki R, Ochiai T, Nakamura T, Kanno A, Kameya T, Yokoyama J. Molecular phylogeny of the genus Asparagus (Asparagaceae) inferred from plastid pet $B$ intron and petD-rpoA intergenic spacer sequences. Plant Spp Biol, 2005; 20(2):121-132.

Goyal RK, Singh J, Lal H. Asparagus racemosus - an update. Indian J Med Sci, 2003; 57(9):408-414.

Gumbo JR, Dzaga RA, Nethengwe NS. Impact on water quality of Nandoni water reservoir downstream of municipal sewage plants in Vhembe District, South Africa. Sustain, 2016; 8(7):597.

Harisha RP, Padmavathy S. Knowledge and use of wild edible plants in two communities in Malai Madeshwara Hills, Southern India Intern J Bot, 2013; 9:64-72.

Jamila F, Mostafa E. Ethnobotanical survey of medicinal plants used by people in Oriental Morocco to manage various ailments. J Ethnopharmacol, 2014; 154(1):76-87.

Kala CP. Indigenous uses, population density, and conservation of threatened medicinal plants in protected areas of the Indian Himalayas. Conserv Biol, 2005; 19(2):368-378.

Kala CP, Sajwan BS. Revitalizing Indian systems of herbal medicine by the National Medicinal Plants Board through institutional networking and capacity building. Curr Sci, 2007; 93:797-806.

Kayani S, Ahmad M, Zafar M, Sultana S, Khan MPZ, Ashraf MA, Hussain J, Yaseen G. Ethnobotanical uses of medicinal plants for respiratory disorders among the inhabitants of Gallies-Abbottabad, Northern Pakistan. J Ethnopharmacol, 2014; 156:47-60.

Kephe PN, Petja BM, Kabanda TA. Spatial and inter-seasonal behaviour of rainfall in the Soutpansberg region of South Africa as attributed to the changing climate. Theor Appl Climatol, 2016; 126(1-2):233-245.

Khan I, AbdElsalam NM, Fouad H, Tariq A, Ullah R, Adnan M. Application of ethnobotanical indices on the use of traditional medicines against common diseases. Evid Based Complement Altern Med, 2014; 2014:21

Kubota S, Konno I, Kanno A. Molecular phylogeny of the genus Asparagus (Asparagaceae) explains interspecific crossability between the garden asparagus (A. officinalis) and other Asparagus species. Theor Appl Genet, 2012; 124(2):345-354

Lulekal E, Asfaw Z, Kelbessa E, Van Damme P. Ethnomedicinal study of plants used for human ailments in Ankober District, North Shewa Zone, Amhara region, Ethiopia. J Ethnobiol Ethnomed, 2013; 9(1):63.

Luseba D, Tshisikhawe MP. Medicinal plants used in the treatment of livestock diseases in Vhembe region, Limpopo province, South Africa. J Med Plants Res, 2013; 7(10):593-601.

Mabogo DEN. Ethnobotany of the Vhavenda. Thesis, Master of Science, Faculty of Science, University of Pretoria, South Africa, 1990.

Mahomoodally MF. Traditional medicines in Africa: an appraisal of ten potent African medicinal plant. Evid Based Compl Altern Med, 2013; $2013: 14$

Mahwasane ST, Middleton L, Boaduo N. An ethnobotanical survey of indigenous knowledge on medicinal plants used by the traditional healers of the Lwamondo area, Limpopo province, South Africa. S Afr J Bot, 2013; 88:69-75.

Mander M, Ntuli L, Diederichs N, Mavundla K. Economics of the traditional medicine trade in South Africa: health care delivery. S Afr Health Rev, 2007; 2007(1):189-196.

Manzo LM, Moussa I, Ikhri K, Goudarzi M, Kalantar M, Kalantar H. Ethnobotanical survey: a comprehensive review of medicinal plants used against gastrointestinal disorders in Niger, West Africa. Eval, 2017; 30:11.

Maroyi A. An ethnobotanical survey of medicinal plants used by the people in Nhema communal area, Zimbabwe. J Ethnopharmacol, 2011; 136(2):347-354.

Masevhe NA, McGaw LJ, Eloff JN. The traditional use of plants to manage candidiasis and related infections in Venda, South Africa. J Ethnopharmacol, 2015; 168:364-372.

Mazid M, Khan TA, Mohammad F. Medicinal plants of rural India: a review of use by Indian folks. Indo Global J Pharm Sci, 2012; 2(3):286-304

Mojahedi M, Naseri M, Majdzadeh R, Keshavarz M, Ebadini M, Nazem E, Isfeedvajani MS. Reliability and validity assessment of Mizaj questionnaire: a novel self-report scale in Iranian traditional medicine. Iranian Red Crescent Med J, 2014; 16(3):e15924.

Mostert TH, Bredenkamp GJ, Klopper HL, Verwey C, Mostert RE, Hahn N. Major vegetation types of the Soutpansberg conservancy and the Blouberg nature reserve, South Africa. Koedoe, 2008; 50(1):32-48.

Mpandeli S. Managing climate risks using seasonal climate forecast information in Vhembe District in Limpopo Province, South Africa. J Sustain Dev, 2014; 7(5):68.

Mukhopadhyay S, Ray S. Chromosome and marker-based genome analysis of different species of Asparagus. Cytol, 2013; 78(4):425-437.

Mulaudzi RB, Ndhlala AR, Kulkarni MG, Van Staden J. Pharmacological properties and protein binding capacity of phenolic extracts of some Venda medicinal plants used against cough and fever. J Ethnopharmacol, 2012; 143(1):185-193.

Mzezewa J, Van Rensburg LD. Effects of tillage on runoff from a bare clayey soil on a semi-arid ecotope in the Limpopo Province of South Africa. Water S Afri, 2011; 37(2):165-172.

Ndhlala AR, Stafford GI, Finnie JF, Van Staden J. Commercial herbal preparations in KwaZulu-Natal, South Africa: The urban face of traditional medicine. S Afr J Bot, 2011; 77(4):830-843.

Norup MF, Petersen G, Burrows S, Bouchenak-Khelladi Y, Leebens-Mack J, Pires JC, Linder HP, Seberg O. Evolution of Asparagus L.(Asparagaceae): Out-of-South-Africa and multiple origins of sexual dimorphism. Mol Phyl Evol, 2015; 92:25-44.

Qasim M, Abideen Z, Adnan MY, Ansari R, Gul B, Khan MA. Traditional ethnobotanical uses of medicinal plants from coastal areas. J Coast Life Med, 2014; 2(1):22-30. 
Raimondo D, von Staden L, Foden W, Victor JE, Helme NA, Turner RC, Kamundi DA, Manyama PA. Red List of South African Plants. Strelitzia 25. South African National Biodiversity Institute, Pretoria, South Africa, 2009.

Ramarumo LJ, Maroyi A, Tshisikhawe MP. Euphorbia pulvinata Marloth: a useful succulent plant species in Vhembe Biosphere Reserve, Limpopo Province, South Africa. Indian J Tradit Know, 2019; 18(1):122-126.

Rikhotso SR. Indigenous Knowledge of Traditional Health Practitioners in the management of Rigoni: grounded theory approach. Doctoral Thesis, Faculty of Health Science, University of Pretoria, South Africa, 2016.

Rokaya MB, Uprety Y, Poudel RC, Timsina B, Münzbergová Z, Asselin H, Tiwari A, Shrestha SS, Sigdel SR. Traditional uses of medicinal plants in gastrointestinal disorders in Nepal. J Ethnopharmacol, 2014; 158:221-229.

Saive M, Frederich M, Fauconnier ML. Plants used in traditional medicine and cosmetics in Mayotte Island (France): An ethnobotanical study. Indian J Traditl Know, 2018; 17(4):645-653.

Scott G, Springfield EP, Coldrey N. A pharmacognostical study of 26 South African plant species used as traditional medicines. Pharmaceut Biol, 2004; 42(3): 186-213.

Semenya SS, Maroyi A. Ethnobotanical survey of plants used by Bapedi traditional healers to treat tuberculosis and its opportunistic infections in the Limpopo Province, South Africa. S Afr J Bot, 2018 [Online] Available via https://doi.org/10.1016/j.sajb.2018.10.010 (Accessed 11 January 2019).

Seshathri K. Antimicrobial properties of Ethiopian chewing sticks against Candida albicans. J Appl Pharm Sci, 2012; 2(2):45-50.

Sigidi MT, Anokwuru CP, Zininga T, Tshisikhawe MP, Shonhai A, Ramaite IDI, Traoré AN, Potgieter N. Comparative in vitro cytotoxic, anti-inflammatory and anti-microbiological activities of two indigenous Venda medicinal plants, Trans Med Comm, 2016; 1(1):1-9.

Stanley MC, Ifeanyi OE, Chinedum OK, Chinwe IA, Emmanuel O, Nwamaka, ON. Antimicrobial activities of Mucuna pruriens (Agbara) on some human pathogens. IOSR J Pharm Biol Sci, 2014; 9(2):09-13.
Umair M, Altaf M,Abbasi AM. An ethnobotanical survey of indigenous medicinal plants in Hafizabad district, Punjab-Pakistan. PLoS One, 2017; 12(6):e0177912.

Van Andel TR, Croft S, Van Loon EE, Quiroz D, Towns AM, Raes N. Prioritizing West African medicinal plants for conservation and sustainable extraction studies based on market surveys and species distribution models. Biol Conserv, 2015; 181:173-181.

Williams VL, Victor JE, Crouch NR. Red listed medicinal plants of South Africa: status, trends, and assessment challenges. S Afri J Bot, 2013; 86: 23-35.

Yao X, Deng J, Huang H. Genetic diversity in Eucommia ulmoides (Eucommiaceae), an endangered traditional Chinese medicinal plant. Conserv Gene, 2012; 13(6):1499-1507.

Yazdanshenas H, Mousavi SA, Tavili A, Shafeian E. Identification of medicinal plants based on modern and indigenous knowledge (case study: Ghasem Abad rangeland, west of Isfahan province, Iran). Rep Opin, 2016; 8(2):1-8

Zschocke S, Rabe T, Taylor JLS, Jäger AK, Van Staden J. Plant part substitution-a way to conserve endangered medicinal plants?. J Ethnopharmacol, 2000; 71(1-2):281-292.

How to cite this article:

Ramarumo LJ, Maroyi A, Tshisikhawe MP. Asparagus sekukuniensis (Oberm.) Fellingham \& N.L.Mey.: A threatened medicinal plant species used by Vhavenda in the Soutpansberg Region, Vhembe Biosphere Reserve, Limpopo province, South Africa. J Appl Pharm Sci, 2019; 9(06):080-085. 